\title{
FORMING A CORRELATION AMONG THE PROPERTIES OF FRESH SELF- COMPACTING CONCRETE USING FUZZY LEAST SQUARES MODEL
}

\author{
Aleksandar Savić \\ University of Belgrade, Faculty of Civil Engineering, Assistant Professor \\ Corresponding author: sasha@imk.grf.bg.ac.rs \\ Marina Aškrabić \\ University of Belgrade, Faculty of Civil Engineering, Teaching Assistant
}

\begin{abstract}
The research presented in this paper was motivated by two problems regarding the properties of fresh self-compacting concrete (SCC). The first problem is that mixture properties can vary owing to different factors (composition, materials, ambient, etc.) and the second problem is that there is usually a restricted group of experimental results. Because of the importance of the properties of fresh SCC mixtures, different tests for determining its passing and filling ability, as well as segregation resistance, have been developed. In this paper, results from $V$-funnel and slump flow tests conducted on seven different concrete mixtures are presented. As a correlation between the measurements of $V$-funnel period $t_{v}$ and the slump flow period $t_{500}$ is usually strong, in this paper, it was expanded using approximate-distance fuzzy least squares method. The goal was to perceive the possible range of these properties and, when applicable, to reduce the number of tests necessary during the production of SCC.
\end{abstract}

Keywords: concrete fresh state properties, self-compacting concrete; fuzzy least square model

\section{FORMIRANJE VEZE IZMEĐU SVOJSTAVA SVJEŽEG SAMOZBIJAJUĆEG BETONA POMOĆU NEIZRAZITE METODE NAJMANJIH KVADRATA}

Sažetak: Istraživanje prikazano u ovom radu povezano je s dva problema koji se javljaju pri ispitivanju svojstava svježih samozbijajućih (SCC) betona. Prvi problem je u vezi s činjenicom da svojstva mješavine mogu varirati zbog različitih čimbenika (sastav, materijali, uvjeti okoline itd.), dok je drugi problem mali broj eksperimentalnih rezultata ispitivanja po mješavini. U sklopu ispitivanja svojstava svježih SCC mješavina, osmišljeni su različiti testovi sposobnosti prolaska i ispunjavanja oplate, kao i otpornosti na segregaciju. U ovome radu prikazane su vrijednosti rezultata ispitivanja metodama V-lijevka i slijeganja razlijevanjem, izmjerene na sedam različitih SCC mješavina. Uobičajeno dobra korelacija između izmjerenih veličina proširena je korištenjem neizrazite metode najmanjih kvadrata. Svrha prikazanog postupka je spoznavanje mogućih graničnih vrijednosti spomenutih svojstava SCC betona i smanjivanje broja potrebnih testova, kada je to moguće, pri proizvodnji SCC betona.

Ključne riječi: svojstva betona u svježem stanju; samozbijajući beton; neizrazita metoda najmanjiih kvadrata 


\section{INTRODUCTION}

Self-compacting concrete (SCC) was introduced in Japan in the mid-80s for the first time. SCC was a step forward in concrete technology compared to normally vibrated concrete owing to its fresh state properties. This type of concrete fills every part of the formwork and surrounds re-bars solely by means of its own weight [1]. In order to produce SCC, conditions related to properties of fresh concrete (filling and passing ability as well as segregation resistance) have to be satisfied. Different testing methods have been introduced in order to determine the properties of fresh SCC. In this paper, the results from two widely used testing methods, both showing the filling ability of SCC, were presented: slump flow and $V$-funnel test.

It should be noted that the properties of a fresh concrete mixture can vary because of different factors (heterogeneity of component materials, temperature, time and mixing method, the person that is conducting the test, etc.). Nevertheless, during concrete production, there is usually a restricted group of experimental results concerning these properties (1-2 results per mixture).

Fuzzy set theory, proposed by L. Zadeh around 1965, represents the basis of the theory of possibility [2]. Fuzzy sets are those sets whose members have degrees of membership. While modeling a problem, one is often forced to define a variable in precise mathematical terms although that is not its nature in reality. This happens in experimental work too, when being forced to estimate the value of a variable, based on limited input such as a restricted number of samples.

It is important to differentiate the terms-'possibility' and 'probability'. It is often the case that external circumstances, i.e., those that make something possible, have a small probability [3]. For example, the problem in question (the measurements of properties of fresh SCC) can be affected by many factors that do not represent probabilistic methods, such as the experience of the conductor of the experiment, his or her mood, concentration, anxiety, interaction with other people at the moment of measuring, and time scales.

The most common approach to fuzzy data processing is either the adaptation of existing algorithms by the extension principle, or the usage of fuzzy arithmetic on models already developed from crisp (deterministic) data. This study used the second approach for creating fuzzy least squares models that can easily be applied to experimental data analysis [4].

In this study, the correlation between measurements of the $V$-funnel period $t_{v}$ and the slump flow period $t_{500}$ was extended using the approximate distance fuzzy least squares method.

\section{METHODS}

\subsection{The method of least squares}

The least squares method is widely used in forming the best fitting correlations between one dependent and one independent variable. In linear regression analysis, after determining the existence of a good linear correlation (straight line) between two observed parameters $x$ and $y$, the mean value of $y$ is assumed to be dependent on the mean value of $\mathrm{x}$ :

$\mu_{y}=\beta_{0}+\beta_{1} x$

In other words, the dependent variable y can be described as the sum of its mean value and relative mistakes noted as $\mathrm{E}$ :

$$
y=\beta_{0}+\beta_{1} x+E,
$$

on condition that the mean value of $E$ equals $0(M(E)=0)$.

Coefficients $\beta_{1}$ and $\beta_{2}$ are calculated from the sample and noted as $b_{1}$ and $b_{0}$, by minimizing the sum of the squares of distances (d) between the measured and the fitting values of $y$ [5]:

$$
\min \sum\left(d_{i}\right)^{2}=\min \sum\left(y_{i}-\left(\beta_{0}+\beta_{1} x\right)\right)^{2}
$$

Therefore, the final explicit forms of the equations for $b_{1}$ and $b_{0}$ are given by (4) and (5): 
$b_{1}=\frac{n \sum_{i=1}^{n} x_{i} y_{i}-\left(\sum_{i=1}^{n} x_{i}\right)\left(\sum_{i=1}^{n} y_{i}\right)}{n \sum_{i=1}^{n} x_{i}^{2}-\left(\sum_{i=1}^{n} x_{i}\right)^{2}}$

$b_{0}=\bar{y}-b_{1} \bar{x}$

\subsection{Fuzzy set theory}

A fuzzy set $A$ in a universe of discourse $X$ is characterized by a membership function $\mu_{A}(x)$, which associates a real number in the interval $[0,1]$ with each element $x$ in $X$. The value of the function $\mu_{A}(x)$ is called the grade of membership of $x$ in $A$ [2].

If $L$ and $R$ are even, non increasing real functions on $[0, \infty)$, satisfying $L(0)=R(0)=1$, fuzzy numbers can take the form:

$\mu_{A}(x)=\left\{\begin{array}{l}L\left(\frac{m-x}{a}\right), \mu \leq m, a>0, \\ R\left(\frac{x-m}{b}\right), \mu \geq m, b>0 .\end{array}\right.$

This is a widely used representation of fuzzy numbers called an LR representation and denoted by $A=$ $(m, a, b)_{L R}$, where $m$ is a modal value of $A$, and $a$ and $b$ are called left and right spread, respectively [6]. This presentation is based on left $(L)$ and right $(R)$ functions that define the fuzzy number. Another notation used in this paper is $A=(a, \beta, \delta)$, where $\beta=m, a=m-a$ and $\delta=m+b$. Triangular fuzzy number $A=(\alpha, \beta, \delta) T$, in the simplest fuzzy form, is defined by the following $L$ and $R$ functions:

$\mu_{A}(x)=\left\{\begin{array}{c}0, x \leq \alpha \\ L=\frac{x-\alpha}{\beta-\alpha}, \alpha<x \leq \beta \\ R=\frac{\delta-x}{\delta-\beta}, \beta<x \leq \delta \\ 0, x>\delta .\end{array}\right.$

Working with fuzzy numbers is possible by using standard mathematical operations. If $A(a, b, c)$ and $B(d, e, f)$ are two triangular fuzzy numbers, defined by the three points explained above, their sum, product, and quotient, respectively, would be equal to [7]:

$A+B=(a+d, b+e, c+f)$

$A \times B=(\min (a \times b, a \times f, c \times d, c \times f),(b \times d), \max (a \times b, a \times f, c \times d, c \times f))$

$A / B=(\min (a / b, a / f, c / d, c / f),(b / d), \max (a / b, a / f, c / d, c / f))$

\subsection{Fuzzy least square method}

Fuzzy regression analysis is used in the evaluation of the functional relationship between the two variables in a fuzzy environment [8]. Many models have been developed in order to apply the method of least squares for the correlation of two variables that can be crisp or fuzzy, forming linear function whose coefficients can also be crisp or fuzzy, depending on the model.

This paper describes the approximate-distance fuzzy least squares method, which was presented by

Dubois and Prade [8]. If $\mathrm{X}_{\mathrm{j}}=\left(\alpha_{\mathrm{xj}}, \beta_{\mathrm{xj}}, \delta_{\mathrm{xj}}\right)$ is the fuzzy input, $\mathrm{A}_{\mathrm{i}}=\left(\alpha_{\mathrm{ai}}, \beta_{\mathrm{ai}}, \delta_{\mathrm{ai}}\right), \mathrm{i}=0, \ldots, \mathrm{k}$ the fuzzy

parameters and $\mathrm{Y}_{\mathrm{j}}=\left(\alpha_{\mathrm{j}}, \beta_{\mathrm{j}}, \delta_{\mathrm{j}}\right)$ is the fuzzy output then the following correlation has been adopted:

$Y_{j}=A_{0}+A_{1} X_{j k}, j=1, \ldots, n$

All the numbers presented are of triangular LR type. The difficulty in treating a model of fuzzy input-output data is that the product $A_{i} X_{j i}$ may not be of $L R$ type. This is why the suggested approximation is used. When applied to $\mathrm{A}_{0}+\mathrm{A}_{1} \mathrm{X}_{\mathrm{j}}=\left(\bar{\alpha}_{\mathrm{j}}, \bar{\beta}_{\mathrm{j}}, \bar{\delta}_{\mathrm{j}}\right)$, the result is the LR fuzzy number $\mathrm{Y}_{\mathrm{j}}=\left(\overline{\alpha_{\mathrm{j}}}, \overline{\beta_{\mathrm{j}}}, \overline{\delta_{\mathrm{j}}}\right)$, where:

$\overline{\alpha_{\mathrm{j}}}=\alpha_{\mathrm{a} 0}+\alpha_{\mathrm{a} 1} \alpha_{\mathrm{xj}}$ 
$\overline{\beta_{\mathrm{j}}}=\beta_{\mathrm{a} 0}+\beta_{\mathrm{a} 1} \beta_{\mathrm{xj}}$

$\overline{\delta_{\mathrm{j}}}=\delta_{\mathrm{a} 0}+\delta_{\mathrm{a} 1} \delta_{\mathrm{xj}}$

It is easy to calculate the distance between two fuzzy numbers $Y_{m j}=\left(a_{y j}, \beta_{y j}, \delta_{y j}\right)$ (based on measured values) and $Y_{\mathrm{j}}$ (fuzzy output) as follows:

$d_{j}=\left(\alpha_{y i}-\overline{\alpha_{j}}\right)^{2}+\left(\beta_{y i}-\overline{\beta_{j}}\right)^{2}+\left(\delta_{y i}-\overline{\delta_{j}}\right)^{2}$

Then the sum of squares of distances $U$ is calculated by [9]:

$U=\sum_{j=1}^{N} \frac{1}{3}\left[\left(\alpha_{y j}-\overline{\alpha_{j}}\right)^{2}+\left(\beta_{y i}-\overline{\beta_{j}}\right)^{2}+\left(\delta_{y i}-\overline{\delta_{j}}\right)^{2}\right]$

Unknown parameters $A_{0}\left(a_{a 0}, \beta_{a 0}, \delta_{a 0}\right)$ and $A_{1}\left(a_{a 1}, \beta_{a 1}, \delta_{a 1}\right)$ are calculated from six linear equations formed by minimizing the value of $\mathrm{U}(16)$, using condition that the first derivative of a function equals 0 at extreme points:

$\frac{\partial U}{\partial N}=0$ for $N=\left(\alpha_{a 0}, \beta_{a 0}, \delta_{a 0}, \alpha_{a 1}, \beta_{a 1}, \delta_{a 1}\right)$

\section{MATERIALS AND EXPERIMENTAL METHODS}

The experimental program consisted of measuring the fresh concrete properties of seven different SCC mixtures through V-funnel and slump flow tests [10,11] (Figure 1). The mixtures were divided into two groups: two referent mixtures (E1 and E2), and five mixtures (LP1, LP2, LP3, LP4, and LP5) containing fly ash as a partial replacement of mineral filler (limestone powder).

Slump flow test procedure consists of the following steps: Abrams' cone is placed on the flat surface and filled with fresh concrete. After $30 \mathrm{~s}$, the cone is carefully lifted, and the timing is started at the same moment. The stopwatch is stopped when the concrete sample reaches a diameter of $500 \mathrm{~mm}$ (lower base diameter of Abrams' cone is $200 \mathrm{~mm}$ ). This period is noted as $t_{500}$. When the concrete sample reaches the final diameter and stops moving, its diameter is measured.

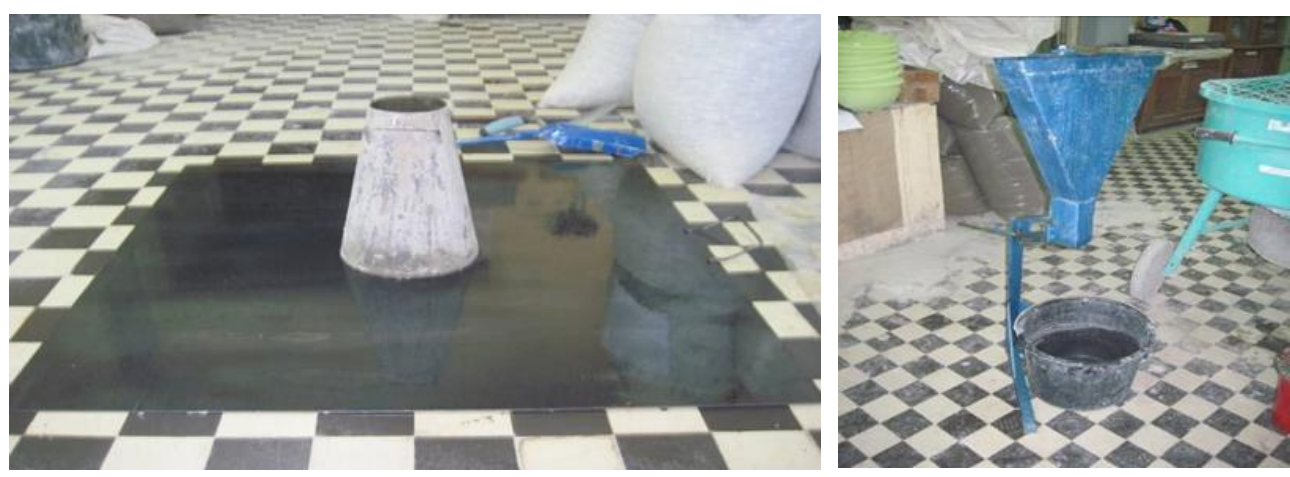

Figure 1 Disposition of the slump flow test (left) and V-funnel test (right) [12]

The V-funnel test is conducted with the use of the equipment shown on the right in Figure 1. A V-funnel of known dimensions and a hinged gate at the bottom is filled with fresh concrete. The stopwatch is started once the gate at the bottom has been opened and concrete starts pouring out. It is stopped when it is possible to see vertically through the funnel into the container below for the first time, and the measured period is noted as $t_{\mathrm{v}}$.

Mixtures containing fly ash were created by varying the percentage and the origin of the fly ash used, without changing the content or nature of other component materials. This research was performed in the Laboratory for materials, Institute for materials and structures, Faculty of Civil Engineering, University of Belgrade.

The river aggregate, originated from the Danube and divided into fractions-I (0/4), II (4/8), and III (8/16) Figure 2, was used for the production of SCC mixes. True and bulk densities of aggregates and other component materials are presented in Table 1, while a series mix design is presented in Table 2 (values are given in $\mathrm{kg} / \mathrm{m}^{3}$ ). 
The amounts of cement, sand, gravel, and the total amount of filler were kept constant in all of the series. With the exception of the first referent mixture $\mathrm{E} 1$ in which this ratio was somewhat smaller, the water/cement ratio was also kept constant.

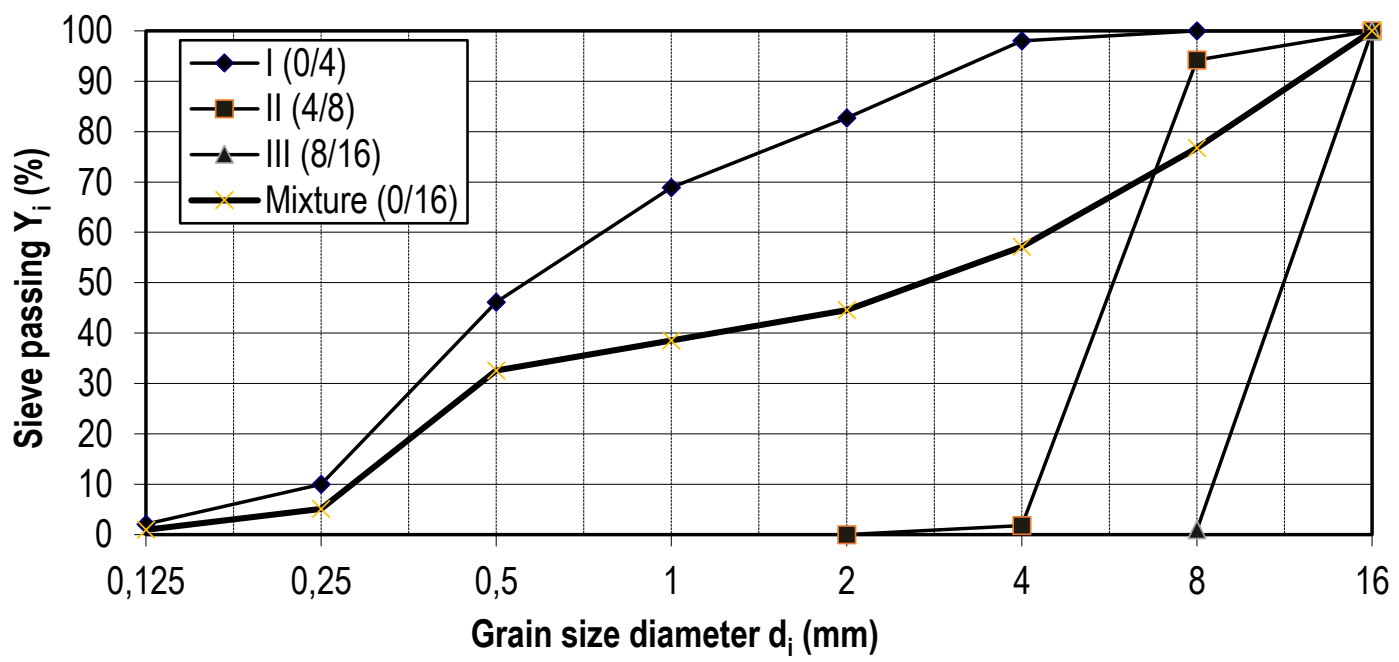

Figure 2 Granulometry of used fractions and aggregate mixture

Table 1 Component materials [11]

\begin{tabular}{cccc}
\hline Component materials & Type lorigin & $\begin{array}{c}\text { True density } \\
{\left[\mathbf{k g} / \mathbf{m}^{3}\right]}\end{array}$ & $\begin{array}{c}\text { Bulk density in loose } \\
\text { state }\left[\mathrm{kg} / \mathbf{m}^{3}\right]\end{array}$ \\
\hline Cement & CEM I (PC 42.5 Lafarge Beočin) & 3040 & 1440 \\
Limestone powder & "Granit Peščar" Ljig & 2720 & 1540 \\
River aggregate & Danube & 2641 & 1600 \\
Fly ash & "Kostolac" & 2210 & 650 \\
Fly ash & "Kolubara" & 2190 & 650 \\
Superplasticizer & "Glenium Sky 690", BASF & 1060 & 1060 \\
\hline
\end{tabular}

Two referent mixtures-E1 and E2-did not contain fly ash, while in mixtures LP1 and LP3 $10 \%$ of limestone filler was replaced with fly ash. Mixtures LP2 and LP4 had $20 \%$ of the limestone filler replaced with fly ash, and finally, mixture LP5 had equal amounts of the two filler components. It should be noted that the fly ash used in mixtures LP1 and LP2 originated from the Power plant "Kostolac," while fly ash in mixtures LP3, LP4, and LP5 originated from the Power plant "Kolubara."

Table 2 Series mix design [11]

\begin{tabular}{cccccccc}
\hline Series & E1 & E2 & LP1 & LP2 & LP3 & LP4 & LP5 \\
\hline Water $W$ & 173 & 183 & 183 & 183 & 183 & 183 & 183 \\
Cement C & 380 & 380 & 380 & 380 & 380 & 380 & 380 \\
Limestone filler & 220 & 220 & 198 & 176 & 198 & 176 & 110 \\
Fly ash & 0 & 0 & 22 & 44 & 22 & 44 & 110 \\
Total amount of filler & 220 & 220 & 220 & 220 & 220 & 220 & 220 \\
Sand (0/4 $\mathrm{mm}$ ) & 840 & 840 & 840 & 840 & 840 & 840 & 840 \\
Coarse aggregate $(4 / 8 \mathrm{~mm})$ & 430 & 430 & 430 & 430 & 430 & 430 & 430 \\
Coarse aggregate $(8 / 16 \mathrm{~mm})$ & 430 & 430 & 430 & 430 & 430 & 430 & 430 \\
Superplasticizer & 7.6 & 7.6 & 7.6 & 7.6 & 7.6 & 7.6 & 11.4 \\
\hline
\end{tabular}




\section{RESULTS AND ANALYSIS}

\subsection{Experimental results}

Results of the measurements of $t_{500}$ and $t_{v}$ are presented in Table 3. Time measured in the $V$-funnel test $\left(t_{v}\right)$ ranged within the limits $9.7 \mathrm{~s}$ and $27.2 \mathrm{~s}$, while $t_{500}$ period ranged from $2.62 \mathrm{~s}$ to $11.32 \mathrm{~s}$. According to the European standard EN 206-9 [13], all the concrete mixtures belonged to the VS2/VF2 category, with $t_{500}$ longer than $2 \mathrm{~s}$ and $t_{v}$ longer than $9 \mathrm{~s}$. The lowest values of both of the parameters were obtained for referent series E2 with higher water/cement (w/c) ratio than series E1, while the highest values were measured for the series LP5 with the highest amount of fly ash. This can be explained by the opposite effects of increasing water and fly ash content. In the case of water content, higher values mean higher $w / c$ and thus lower $t_{v}$ and $t_{500}$ values, provided adequate segregation resistance is achieved. In the case of fly ash content, higher values lead to a drop in workability and flowability that is reflected in the results obtained from all mixtures containing fly ash (LP1 to LP5). Since fly ash was used in its original state (without sieving or mechanical activation), the stated results differ from those commonly found in the literature $[14,15]$, in which very fine fly ash was used. It was also noticed that the measured values have similar growth (series with measured lower $t_{500}$ values, also had lower tv values and vice versa).

Table 3 Results of slump flow test and V-funnel test [11]

\begin{tabular}{cccccccc}
\hline Series & E1 & E2 & LP1 & LP2 & LP3 & LP4 & LP5 \\
\hline$t_{500}(s)$ & 7.22 & 2.62 & 5.00 & 6.72 & 5.71 & 10.91 & 11.32 \\
$t_{V}(s)$ & 22.31 & 9.73 & 16.87 & 20.17 & 15.92 & 22.46 & 27.21 \\
\hline
\end{tabular}

\subsection{Least squares regression method applied to the experimental results}

A linear correlation between the two measured parameters, $t_{500}$ and $t_{v}$, had been established using the least squares method as shown in Figure 3. By comparing values of the correlation coefficient for differently shaped fitting functions, it was established that linear regression with $R^{2}=0.8547$ was a satisfactory choice.

Correlation coefficient is a quantity that confers the quality of a least squares fitting to the original data [5]. If t500 $_{50}$ represented by $\mathrm{x}$ and $\mathrm{t}_{\mathrm{v}}$ as $\mathrm{y}$, the correlation coefficient equals:

$R=\frac{\sum_{i}\left(x_{i}-\bar{x}\right)\left(y_{i}-\bar{y}\right)}{\sqrt{\sum_{i}\left(x_{i}-\bar{x}\right)^{2}} \sqrt{\sum_{i}\left(y_{i}-y\right)^{2}}}$

As shown in Figure 3 , linear regression coefficients $b_{1}$ and $b_{0}$ were calculated to determine the correlation between measured periods $t_{500}$ and $t_{v}$. They amounted to $b_{1}=1.666$ and $b_{0}=7.4573$. Finally, the adopted function was:

$t_{v}=1.666 t_{500}+7.457$

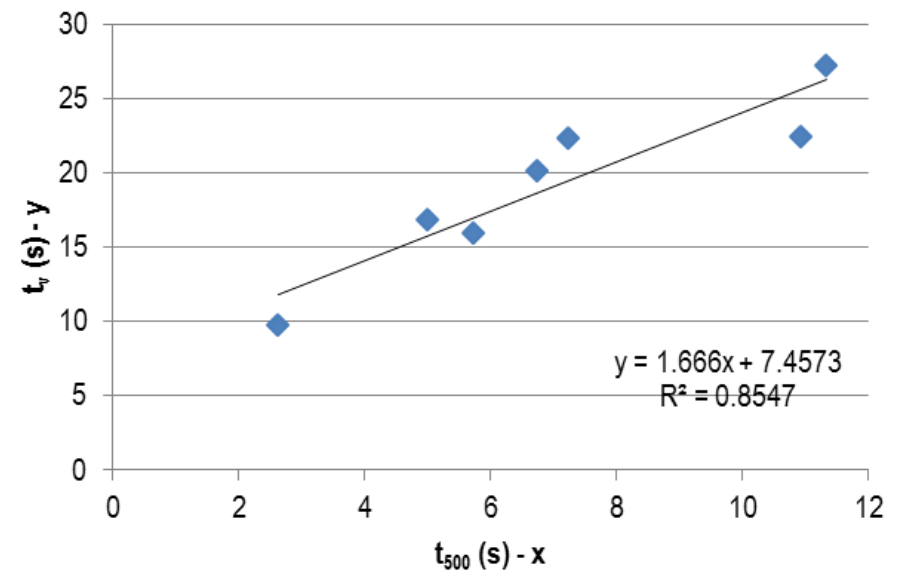

Figure 3 Correlation between measured periods $t_{500}$ and $t_{v}$ using least squares method 
This correlation between $t_{500}$ and $t_{v}$ leads to the conclusion that one of these tests could be excluded and its values estimated based on the other. A comparison of the boundaries for the VS2/VF2 category with the obtained correlation leads to a similar conclusion (when $t_{500}=2 \mathrm{~s}$ then $t_{v}=1.666 t_{500}+7.4573=10.8 \mathrm{~s}$, where $t_{v}=9 \mathrm{~s}$ is the lower boundary for the class). One must be careful in such an analysis, since good results obtained in the V-funnel and slump flow tests do not guarantee good properties regarding stability and passing ability.

\subsection{Fuzzy least squares method applied to the experimental results}

The aim of this paper was to establish the possible boundaries for the correlation between two measured values, as shown in Figure 4. These boundaries were established using the approximate distance fuzzy least squares method.

For the purpose of this calculation, both $t_{v}$ and $t_{500}$ were defined as triangular fuzzy numbers. Left and right spreads were adopted based on the previous trials and experiences with the fresh state behavior of presented mixtures. The measured values presented in Table 3 were taken to be the most possible ones.

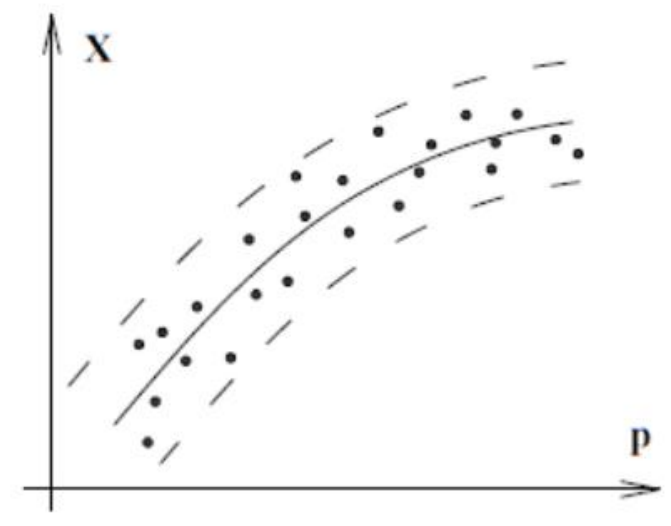

Figure 4 Correlation function with possible upper and lower boundary

Time periods $t_{500}$ and $t_{v}$, presented as fuzzy numbers with graphical representations are shown in Table 4 for all of the series. Unknown parameters $A_{0}\left(a_{a 0}, \beta_{a 0}, \delta_{a 0}\right)$ and $A_{1}\left(a_{a 1}, \beta_{a 1}, \delta_{a 1}\right)$ are calculated by minimizing sum of squares of distances between measured and fitted $Y$ values, noted as $U(16,17)$.

Applying this methodology numerically, the fuzzy coefficients of linear regression are obtained:

$A_{0}=\{6.938,7.457,8.196\}$ and $A_{1}=\{1.593,1.666,1.699\}$

Finally, the results of applying the fuzzy least square method are presented graphically in Figure 5 . Function III is the same as the one gained from the least squares method, while functions I and II were defined using the lower and upper boundaries of the calculated coefficients (II: $t_{v}=1.593 t_{500}+6.938$ and III: $\left.t_{v}=1.699 t_{500}+8.196\right)$.

The functions presented in Figure 5 simulate the boundaries of the possible outcomes of a higher number of measurements that might be performed on different SCC mixtures with these component materials. This provides a good estimation of $t_{v}$ and $t_{500}$ ranges in different mixtures, and at the same time decreases the number of necessary tests. The deviations from the measured values did not have a great influence on the adopted linear correlation function. 
Forming a correlation among the properties of fresh self-compacting concrete using fuzzy least squares model

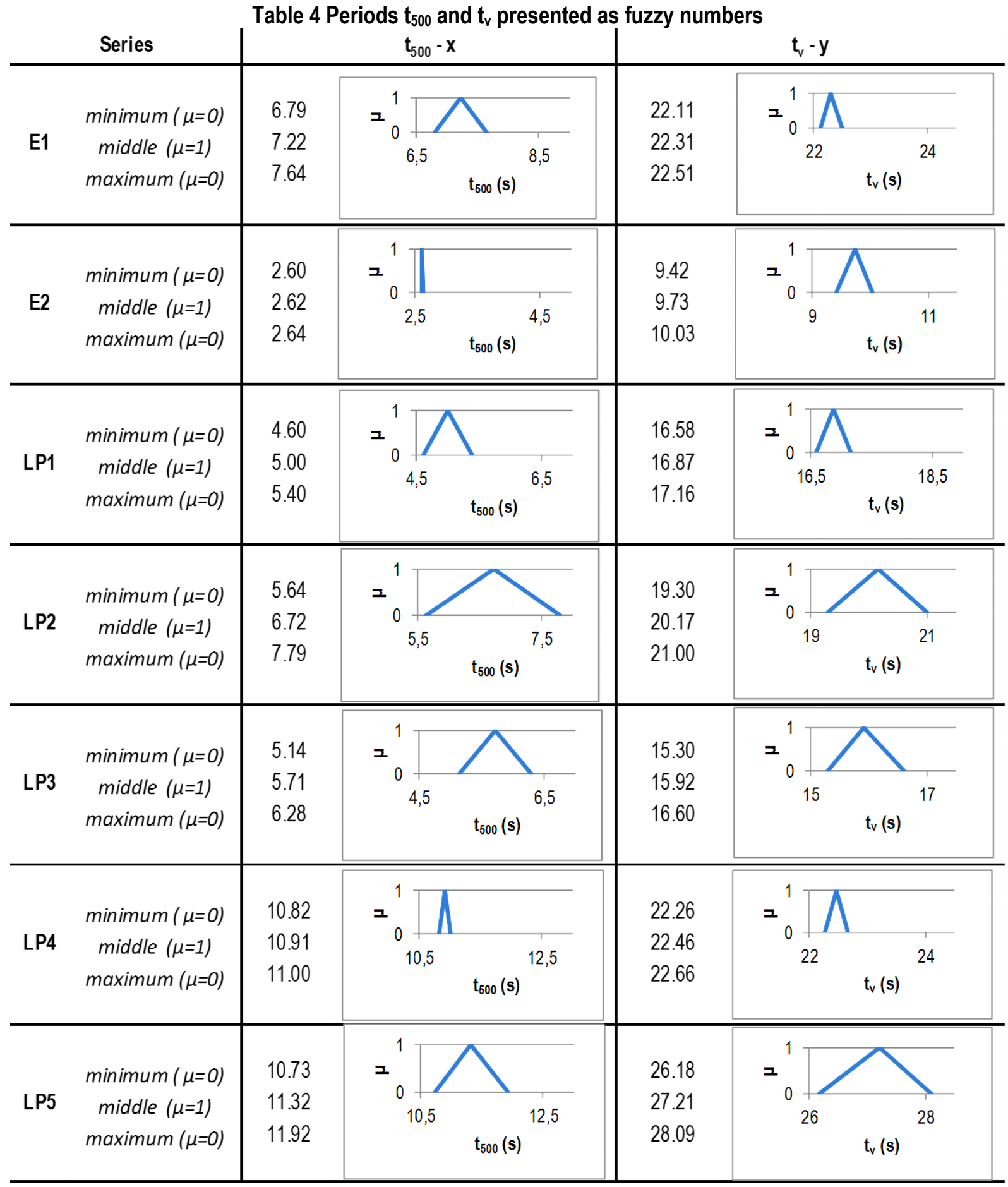




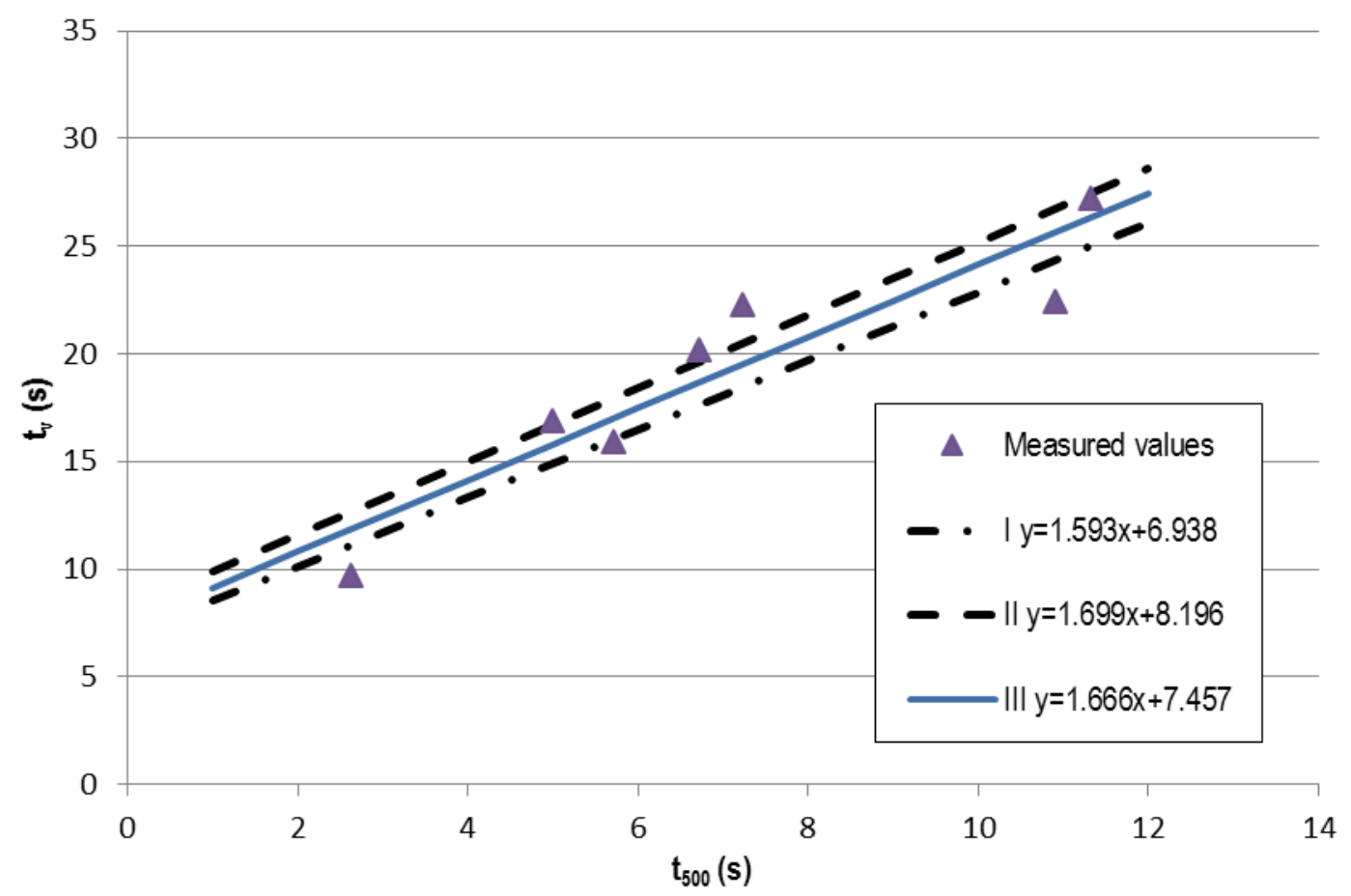

Figure 5 Upper and lower boundary of linear correlations between the periods $t_{500}$ and $t_{v}$ for the tested series

\section{CONCLUSION}

As stated before, the properties of fresh concrete, especially important for SCC, are influenced by different factors. On the other hand, the number of the collected data points is almost always insufficient for a more detailed statistical analysis. These facts lead us to the conclusion that, once a good correlation has been established between the data, it can be broadened using a probabilistic method-in this case, fuzzy set theory.

In this paper, seven experimental results from $V$-funnel and slump flow tests ( $t_{v}$ and $t_{500}$ ) obtained from different mixtures were analyzed, and the correlation between measured values was formed. A number of testing results were too small to provide complete confidence in the regularity of the fitting function. That is why the fuzzy least squares method was applied, with satisfying results. The adopted fuzzy numbers had different spreads that ranged from $0.02 \mathrm{~s}$ to $1.08 \mathrm{~s}$ for $t_{500}$, and from $0.2 \mathrm{~s}$ to $1.03 \mathrm{~s}$ for $\mathrm{t}_{\mathrm{v}}$. Nevertheless, the calculated fuzzy coefficients of the correlation function had left and right spreads that amounted to only 0.738 and 0.519 for $A_{0}$, and 0.073 and 0.033 for $A_{1}$.

It can be concluded that deviations from the measured values did not have a great influence on the adopted linear correlation function. In addition, the lower (function I) and upper limits (function II) for determining the possible outcomes for $t_{v}$ were established. This can help in the evaluation of new concrete mix designs, e.g., with the use of different amounts of fly ash, by using only one control testing method for concrete filling ability during trial testing.

\section{ACKNOWLEDGMENTS}

The work reported in this paper is a part of the investigation within the research project TR 36017 "Utilization of byproducts and recycled waste materials in concrete composites in the scope of sustainable construction development in Serbia: investigation and environmental assessment of possible applications", supported by the Ministry of Education, Science and Technological Development, Republic of Serbia. This support is gratefully acknowledged. 


\section{References}

[1] European Project Group, 2005: European Guidelines for Self-Compacting Concrete: Specification, Production and Use

[2] Zadeh, L. A., 1965: Fuzzy Sets, Information and Control, pp. 338-353, http://dx.doi.org/10.1016/S00199958(65) $90241-X$

[3] Praščević, Z. : Primena teorije mogućnosti u planiranju realizacije projekata, Izgradnja 1/89, pp. 9-13,

[4] Diamond, F. 1988: Fuzzy Least Squares, Information Sciences, 46(3), pp. 141-157, http://dx.doi.org/ 10.1016/0020-0255(88)90047-3

[5] Mališić, J.; Jevremović, V. 2014: Statističke metode u meteorologiji i inženjerstvu, Matematički fakultet Univerziteta u Beogradu, Univerzitetski centar za primenjenu statistiku, Univerzitet u Novom Sadu, Beograd

[6] Dubois, D.; Prade, H. 1980: Fuzzy Sets and Systems: Theory and Applications, Academic Press, New York

[7] Larsen H. L.: Fundamentals of Fuzzy Sets and Fuzzy Logic, Aalborg University Esbjerg, FL-14b pp. 1-6

[8] Yang, M. S.; Lin, T. S. 2002: Fuzzy least-squares linear regression analysis for fuzzy input-output data, Fuzzy Sets and Systems, 126(3), pp. 389-399, http://dx.doi.org/10.1016/S0165-0114(01)00066-5

[9] Torfi, F.; Farahani, R. Z.; Mahdavi, I. 2011: Fuzzy Least-Squares Linear Regression Approach to Ascertain Stochastic Demand in the Vehicle Routing Problem, Applied Mathematics, 2, pp. 64-73, http://dx.doi.org/ 10.4236/am.2011.21008

[10] SRPS EN 12350-8:2012 Ispitivanje svežeg betona - Deo 8: Samougrađujući beton - Ispitivanje rasprostiranja sleganjem, Institut za standardizaciju Srbije,

[11] SRPS EN 12350-9:2012 Ispitivanje svežeg betona - Deo 9: Samougrađujući beton - Ispitivanje pomoću Vlevka, Institut za standardizaciju Srbije,

[12] Savić, A. 2015: Istraživanje svojstava svežeg i očvrslog samozbijajućeg betona sa mineralnim dodacima na bazi industrijskih nusprodukata, Doktorska disertacija, Univerzitet u Beogradu, Građevinski fakultet, Beograd, mentori: prof. dr Dragica Jevtić, prof. dr Tatjana Volkov Husović

[13] EN 206-9:2010 Concrete. Additional rules for Self-Compacting Concrete (SCC)

[14] Brown, J. H. 1982: The strength and workability of concrete with PFA substitution. Proceedings, International Symposium on the Use of PFA in Concrete, University of Leeds, England, pp. 151-161.

[15] Wesche, K. 2005: Fly Ash in Concrete: Properties and performance (Rilem Report 7), Report of Technical Committee 67-FAB Use of Fly Ash in Building, Taylor \& Francis e-Library, 